\section{Sedimentary ancient DNA from Lake Skartjørna, Svalbard: Assessing the resilience of arctic flora to Holocene climate change}

Inger Greve Alsos, ${ }^{1}$ Per Sjögren, ${ }^{1}$ Mary E Edwards, ${ }^{2,3}$ Jon Y Landvik, ${ }^{4}$ Ludovic Gielly, ${ }^{5,6}$ Matthias Forwick, ${ }^{7}$ Eric Coissac, ${ }^{5,6}{ }^{\text {Antony G Brown }}{ }^{2}$, Leif V Jakobsen, ${ }^{5}$ Marie K Føreid' and Mikkel W Pedersen ${ }^{\beta}$

\section{Abstract}

Reconstructing past vegetation and species diversity from arctic lake sediments can be challenging because of low pollen and plant

macrofossil concentrations. Information may be enhanced by metabarcoding of sedimentary ancient DNA (sedaDNA). We developed a Holocene record from Lake Skartjørna, Svalbard, using sedaDNA, plant macrofossils and sediment properties and compared with published records. All but two genera of vascular plants identified as macrofossils in this or a previous study were identified with sedaDNA. Six additiona vascular taxa were found, plus two algal and 12 bryophyte taxa by sedaDNA analyses, which also detected more species per sample than macrofossil analysis. A shift from Salix polaris-dominated vegetation with Koenigia islandica, Ranunculaceae spp. and the relatively thermophilic species Arabis alpina and Betulat to Dryas octopetala-dominated vegetation 6600-5500 cal. BP suggests a transition from moist conditions $1-2^{\circ} \mathrm{C}$ warmer than today to colder/drier conditions. [AQ: 1] This coincides with a decrease in runoff, inferred from core lithology, and an independent record of declining lacustrine productivity. This mid-Holocene change in terrestrial vegetation is broadly coincident with changes in records from marine sediments off the west coast of Svalbard. Over the Holocene sedaDNA records little floristic change, and it clearly shows species persisted near the lake during time intervals when they are not detected as macrofossils. The flora has shown resilience in the presence of a changing climate, and, if future warming is limited to $2^{\circ} \mathrm{C}$ or less, we might expect only minor floristic changes in this region. However, the Holocene record provides no analogues for greater warming.

\section{Keywords}

ancient DNA, Arctic, climate change, metabarcoding, plant macrofossils, vegetation reconstruction

Received 26 March 2015; revised manuscript accepted 21 September 2015

\section{Introduction}

Future global warming is expected to be strongest in the Arctic, with summer temperatures likely $2-4{ }^{\circ} \mathrm{C}$ (or more) higher than today and sea-ice cover drastically reduced (Collins et al., 2013; Xu et al., 2013). Our understanding of likely responses to future environmental change is aided by studies of the past, such as the reconstruction of long-term vegetation dynamics and species diversity patterns in relation to past climate change. While most arctic vegetation reconstructions to date have been based on pollen and macrofossils (e.g. Bennike, 2013; Bigelow, 2013; Kienast, 2013), the potential of a molecular approach has recently been demonstrated (Anderson-Carpenter et al., 2011; Willerslev et al., 2003, 2014). Analysis of sedimentary ancient DNA (sedaDNA) augments information on past species composition derived from conventional techniques (Giguet-Covex et al., 2014; Jørgensen et al., 2012; Pansu et al., 2015; Parducci et al. 2012b; Pawlowska et al, 2014). In the Arctic, cold conditions favour good preservation of material, and small floras allow the development of comprehensive molecular reference libraries (Sønstebø et al., 2010), both of which contribute to effective results. However, further exploration of the method is required (Pedersen et al., 2015), particularly in relation to lake sediments, which are important palaeo-archives in the Arctic (e.g. Kaufman et al., 2009; Over-peck et al., 1997).

Pollen analyses of arctic sediments can show compositional changes in herb-dominated tundra vegetation (e.g. Cwynar, 1982; Fredskild, 1973), but palynologists must deal with the low pollen concentrations that result from low pollen productivity (Lamb

University of Tromsø - The Arctic University of Norway, Norway

University of Southampton, Highfield Campus, UK

"University of Alaska Fairbanks, USA

"Norwegian University of Life Sciences, Norway

University Grenoble Alpes, LECA, France

'LECA, CNRS, France

'Department of Geology, University of Troms $ø$ - The Arctic University of Norway, Norway
Commented [i1]: ,

Commented [i2]: Antony G. Brown2

Commented [i3]: it

Commented [i4]:

Commented [i5]:

Commented [i6]:

Commented [i7]: 
"Centre for GeoGenetics, Natural History Museum of Denmark, University of Copenhagen, Denmark

Corresponding author:

Inger Greve Alsos, Tromsø Museum, University of Troms $\varnothing$ - The Arctic University of Norway, NO-9037 Tromsø, Norway. Email: inger.g.alsos@uit.no
Commented [i9]: Unmarked set by ial007 
and Edwards, 1988). Indeed, in the High Arctic, pollen concentrations may be too low to provide sufficient material for reliable reconstructions (Birks, 1991; Rozema et al., 2006). Pollen grains are variably resolved taxonomically, particularly in the Arctic, where tax in several diverse groups are barely distinguishable below family level (e.g. Poaceae, Cyperaceae, Salicaceae). In contrast, macrofossil records can be more floristically informative, as they are often identifiable to genus or species level, and they are also more representative of the local vegetation (Birks, 2003; Birks and Birks, 2000). However, deposition and preservation of identifiable plant remains vary considerably among species and sites.

How vegetation is represented by sedaDNA is less well understood. Yoccoz et al. (2012) demonstrated that the amount of DNA

(i.e. sequence abundance) in modern soil samples was related to local above-ground biomass. Noisy but significant linear relationships showed an approximate 1:1 relationship for graminoids, whereas woody taxa were under-represented and forbs over-represented in the DNA. These patterns may reflect the absolute amount of DNA in the soil, as determined by litter turnover rate, lignin content and root:shoot ratio (Yoccoz et al., 2012). To date, we have no information as to whether such a relationship holds with DNA in lake sediments.

Several studies based on a range of depositional environments, different floras and varying levels of taxonomic resolution have compared sedaDNA and pollen. The conclusions are hot readily generalized; results tend to show higher taxonomic resolution in sedaDNA but more taxa identified overall in pollen. A generally low floristic overlap between pollen and sedaDNA (Jørgensen et al., 2012; Parducci et al., 2012b, 2013; Pedersen et al., 2013) may indicate that sedaDNA is of local origin (Haile et al., 2007, 2009; Willerslev et al., 2007), whereas in the localities studied, pollen is probably derived from the regional vegetation. Indeed, comparisons of sedaDNA and plan macrofossils show higher taxonomic overlap, which would be expected if both reflect local sources (Jørgensen et al., 2012; Parducci et al., 2012b; Pedersen et al., 2013; Porter et al., 2013), with one exception (Parducci et al., 2015).

The sedaDNA technique potentially has several advantages: a standardized and objective mode of identification, high taxonomic resolution and (when techniques are well established) more time-efficient production of results. The detailed floristic information retrieve (as with macrofossils) can contribute to, for example, biodiversity estimates and interpretations of environmental changes using indicator taxa. An effective exploration of the ability of sedaDNA to reveal past plant community composition should ideally be based on floras that are well known and should employ careful comparisons across levels of taxonomic resolution. The Svalbard archipelago is an ideal study system to investigate the potential of sedaDNA. The majority of the flora is available in a DNA taxonomic reference library (Sønstebø et al., 2010), assuring reliable assignment to taxon. The number of vascular plant species is low (176), and plant distributions, therma requirements and geological preferences are well known (Alsos et al., 2015; Elvebakk, 1982, 1989). Potential modern vegetation analogues are well described from the archipelago (Elvebakk, 1994, 2005; Klimešová et al., 2012).

Spitsbergen, the largest island in the Svalbard archipelago, was almost completely glaciated at the Last Glacial Maximum (Hormes et al, 2013; Ingólfsson and Landvik, 2013; Landvik et al., 1998). The fjords on western Spitsbergen were deglaciated between $c$. 14,100 an 11,200 cal. BP (e.g. Baeten et al., 2010; Forwick and Vorren, 2009; Hald et al., 2004; Mangerud et al., 1992). While late-glacial vegetation records are lacking from this region (reviewed in Birks et al., 1994), a number of Holocene palaeoecological records (9000 cal. BP and onwards) are available (see Bernardova and Kosnar, 2012). Based on a plant macrofossil record from the same lake that is the subject of this study, Birks (1991) concluded that while vegetation cover has decreased over time, the flora has not changed substantially in the las 8000years, suggesting long-term stability in species composition. This contention provides an interesting target to assess using the sedaDNA approach.

Lake Skartjørna was chosen because of the detailed plant macrofossil record mentioned above, which covers most of the Holocene an includes several species outside their present geographical distribution (Arabis alpina, Salix herbacea, Harrimanella hypnoides; Birks, 1991). In addition, the depositional environment of this site is well studied (Holmgren et al., 2010; Landvik et al., 1987). The main goals for this study were to (1) compare taxonomic resolution, taxonomic overlap and detection success of the sedaDNA and plant macrofossil records; (2) use sedaDNA data, plant macrofossil and sediment analyses to infer past environmental change; (3) consider what Holocene vegetation change can tell us about the impact on vegetation of expected future warming in the High Arctic; and (4) explore whethe sedaDNA increases our understanding of past flora and vegetation when combined with other proxy approaches.

\section{Methods}

\section{Study site}

Lake Skartjørna (previously Skardtjørna) is located on the west coast of Spitsbergen (61m.a.s.l., Figure 1). It is dammed by prominent raised beach ridge that forms the postglacial marine limit at $65 \mathrm{~m}$.a.s.l., and it has been cut off from the sea since formation about $13,000 \mathrm{cal}$. BP (Landvik et al. 1987). An almost circular 7.5m deep basin east of the centre constitutes the deepest part of the lake. The lake area is $0.10 \mathrm{~km}^{2}$ and the total catchment is $1.24 \mathrm{~km}^{2}$ (Holmgren et al., 2010). Air photos from recent decades show the lake level fluctuating by $1-2 \mathrm{~m}$ (Figure 1). The site was visited for coring from lake ice in March 2013 and then again on 9 September 2015 to record the flora and geology of the catchment area. The catchment of the lake is located on the South facing thrustal scarp of the junction between the Southwestern Basement Province dominated by metamorphic rocks (phyllites and quartzite) and the post Caledonian orogeny lithologies that make up the bedrock slopes draining into the lake (Hjelle et al., 1986; Oht et al., 1991; Dallmann, 2015).[AQ: 2] The northern bedrock slopes on the Neoprotozoic Løvliebreen formation of psammo-pelitic phyllite, while the southern slope is on limestone with magnetite and haematite layers of the Malmberget unit. The north eastern bedrock free-face also revealed a zone of mineralization and enhanced weathering. However, parts of the northern and all of the southern bedrock slopes are obscured by ice-cored and vegetation-free morainic ridges that contain a wider range of lithologies including marbles, shales, siltstones, dolomitic limestone and sandstones predominantly of wider range of lithologies including marbles, shales, siltstones, dolomitic limestone and sandstones predominantly of
age. These lateral moraines also contain a sand and silt-rich matrix which contributes sediment directly into the lake. It is also pertinent that most of these slopes are steep with free faces above steep debris-cones. There is therefore in this small catchment a direct coupling between slope conditions and sediment delivery into the lake, making it highly sensitive to changes in snowmelt runoff, active layer instability and vegetation cover. Although not observable, it is likely that the upper raised beach ridge that bounds the lake to the west foverviews a terminal moraine. The axial drainage of the catchment to the

Commented [i10]: spelled

Commented [i11]: in

Commented [i12]: composed of

Commented [i13]: moraine

Commented [i14]: is deposited on top of

Commented [i15]: its

Commented [i16]:

Commented [i17]:

Commented [i18]:

Commented [i19]: comprise

Commented [i20]:

Commented [i21]:

Commented [i22]: Carboniferous

Commented [i23]:

Commented [i24]: 
lake is from the drainage from Tjørnskaret pass (Figure 1), which has formed a fan delta along the northeast shore of the lake. A small component of clastic sediment is also expected to derive from lakeshore erosion and wind transport.

The site is within the bioclimatic zone B (northern arctic tundra zone, Elvebakk, 2005; Walker et al., 2005). The catchment area is characterized by polygon features and vegetation with 


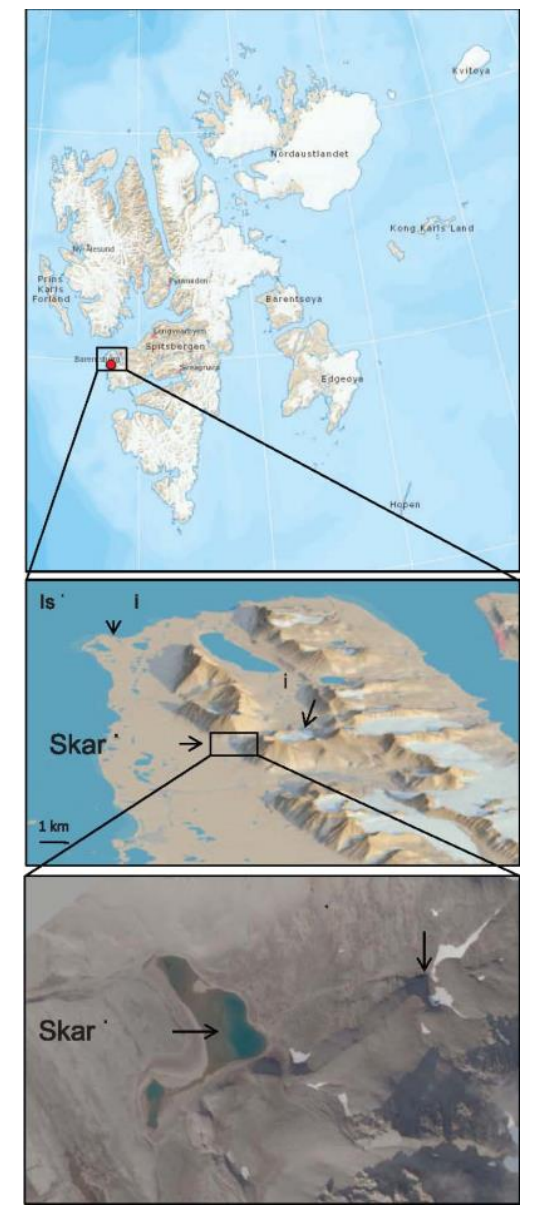

Figure 1. The arctic archipelago Svalbard (with the exception of the island Bjørnøya to the south) and the Lake Skartjørna.

overall only $10 \%$ cover, except locally in more stable sites where there is up to $100 \%$ vegetation. The vegetation mosaic comprises wet sites dominated by bryophytes, unstable mesic sites dominated by Saxifraga aizoides and/or the trailing form of Saxifraga oppositifolia $\|$ stable mesic sites dominated by Salix polaris, Silene acaulis and Bistorta vivipara heath. Other common species are Saxifraga cespitosa, Oxyria digyna, Luzula nivalis, Luzula confusa and Papaver dahlianum. There are scattered occurrences of Puccinellia vahliana, Saxifraga svalbardensis, Micranthes tenuis, Cochlearia groenlandica, Sagina nivalis, Poa alpina, $P$. pratensis, Cerastium arcticum and $C$. regelii. In the upper part of the catchment area, at Tjørnskaret, patches of $100 \%$ bryophyte cover with $10 \%$ cover of Huperzia arctica occur, indicating slightly warmer growth conditions (AAlsos and Brown, 2015, personal observation). The annual precipitation measured at Isfjord Radio, $12 \mathrm{~km}$ north of the lake
(Figure 1), is $320-470 \mathrm{~mm}$ (Førland et al., 2011). Mean July and February temperatures in the period $1961-1990$ were $4.8^{\circ} \mathrm{C}$ and $-12.4^{\circ} \mathrm{C}$, respectively, with an annual mean of $-5.1^{\circ} \mathrm{C}$ (http:/ eklima.met.no ).

\section{Sediment coring and sub-sampling}

Ground-penetrating radar was used to locate the deepest sediment package $\left(77.96167^{\circ} \mathrm{N}, 13.81958^{\circ} \mathrm{E}\right)$. A $5.3 \mathrm{~m}$ sediment core (7.40-12.70m below ice surface) was retrieved using a Nesje corer (Nesje, 1992) loaded with a $6 \mathrm{~m}$ long, $10 \mathrm{~cm}$ diameter PVC tube. The upper $65 \mathrm{~cm}$ of the core consisted of soft/liquid sediments that had to be discarded in the field. The core was split into three sections to facilitate transport and handling. Core tops were plugged and taped immediately to prevent contamination. When splitting the core, some sediment and the lowermost $5 \mathrm{~cm}$ from the uppermost section|was lost ( $\mathrm{sec}-$ tion $\mathrm{C}, 166 \mathrm{~cm}$ below sediment surface). In order to account fo this, a $5 \mathrm{~cm}$ hiatus was added $(166-171 \mathrm{~cm})$ and the applied depth of the core segment were adjusted upwards. All depths are given as centimetres below sediment surface.

The core was kept at $1-10^{\circ} \mathrm{C}$ during transport and subsequently stored at $4{ }^{\circ} \mathrm{C}$ at the University of Troms (UiT). It was late transported to the Centre for GeoGenetics, Copenhagen University, where it was split in half. From one half, sub-samples of $8 \mathrm{~g}$ were taken using sterile disposable syringes. The core was returned to Troms $\varnothing$, where the same core half was sub-sampled for radiocarbon dating, loss-on-ignition (LOI), grain-size analysis and plant macrofossil analysis. The second half was kept intact a a reference core and exclusively used for line-scan imaging and non-destructive $\mathrm{x}$-ray fluorescence core scanning.

\section{Radiocarbon dating and chronology}

Twelve samples of plant macrofossils were AMS radiocarbon dated at the Poznan Radiocarbon Laboratory of the Adam Mickiewicz University, Poland (Table 1). Calibration was done using IntCal13 (Reimer et al., 2013), and the age-depth relationship wa modelled by Bayesian statistics using the program MacBacon 2.2 with default settings (Blaauw and Christen, 2011). The sedimentation rate was based on the age-depth relationship and rounded off to closest $0.1 \mathrm{~mm} / \mathrm{yr}$.

\section{Lithological analyses}

Colour line-sean images with a resolution of approximately 70 $\mu \mathrm{m}$ were acquired using a Jai L-107CC 3 CCD RGB Line Scan Camera installed on an Avaatech XRF core scanner. The sedimen surface was subsequently covered with $4-\mu \mathrm{m}$-thick Ultralene foil, and qualitative element-geochemical analyses were carried out with the Avaatech XRF core scanner. The measurements were carried out at $10 \mathrm{~mm}$ steps (each step covered $10 \mathrm{~mm}$ down-core and $12 \mathrm{~mm}$ cross-core). Instrument settings were $10 \mathrm{kV}, 1000 \mu \mathrm{A}$, 10 s count time and no filter. Data processing was performed using WinAxil version 4.5.6. The results are presented as ratios of selected elements divided by the most conservative element, $\mathrm{Ti}$, to minimize the influence of water and matrix effects (Tjallingii et al., 2007; Weltje and Tjallingii, 2008). Scanning failed for a part of the core $(319-341 \mathrm{~cm})$, and re-scanning revealed problems with the calibration; we thus had to exclude this part to avoid risks of bias.

LOI and water content were measured using $10 \mathrm{~g}$ sub-samples every $4 \mathrm{~cm}$, with intervals occasionally adjusted in relation to lithological boundaries. Samples were weighed, dried overnight a
Commented [i35]:

Commented [i36]:

Commented [i37]:

Commented [i38]:

Commented [i39]: UiT - The Arctic University of Norway

Commented [i40]:

Commented [i26]: Please replace this figure with new version.

Commented [i27]: of

Commented [i28]:

Commented [i29]: $X$ denotes coring site.

Commented [i30]:

Commented [i31]:

Commented [i32]:

Commented [i33]:

Commented [i34]: 
$105^{\circ} \mathrm{C}$, weighed again, combusted for $3 \mathrm{~h}$ at $550^{\circ} \mathrm{C}$, allowed to cool in a desiccator and re-weighed. Water content is based on the dry weight and expressed as a percentage of the wet (original) weight. LOI is based on the post-ignition weight and expressed as a percentage of the dry weight (see Heiri et al., 2001). 
cular plant species in Svalbard and the majority of those found in neighbouring territories, as well as the circum-arctic region, are in the local reference library, we prioritized matches against this database. On the other hand, if taxa were lacking in the local library, there may have been no assignment, or an erroneous one. Therefore, we also made comparisons with a second reference library generated after running ecopcr on the global EMBL database (release r117 from October 2013). Sequences assigned to non-native taxa were blasted to check for potential wrong assignments (http://www.ncbi.nlm.nih.gov/blast/).

Extreme caution must be taken before accepting a taxonomic assignment in an environmental sample (Pedersen et al., 2015). Accordingly, to avoid any misidentifications, only sequences matching $100 \%$ to reference library entries and occurring as at matching $100 \%$ to reference library entries and occurring as at
least 10 reads per PCR repeat were kept. The following were also removed: (1) sequences having higher frequencies in negative controls than in samples, (2) sequences occurring in $<3$ repeats in total (i.e. across all samples), (3) sequences belonging to food (4) sequences suspected to be droplet contaminants or overflow from samples from another study run at the same time. One complete sample, which appeared as an outlier in terms of low number of reads and repeats, was excluded (Supplementary Table S1, available online). By applying these thresholds, rare taxa were possibly missed but potential errors were removed. In four cases, two sequences were assigned to the same taxon and combined (Saxifraga oppositifolia, Micranthes, Pedicularis and Dicranaceae). For sequences that matched several taxa or were assigned to genus level only, the likely taxa based on the current native flora of Svalbard were listed as potential species. Taxa identified in more than two of the four PCR repeats per sample were assumed to be certain, whereas the validity of taxa found in fewer repeats was assessed carefully. 
Plant macrofossil analysis

Macrofossils were analysed for direct comparison with the sedaDNA record as well as for biostratigraphic correlation with the record of Birks (1991). In total, 36 samples were collected contiguously as $4-6 \mathrm{~cm}$ slices. Sediment volume was determined by water displacement. Sample volumes were approximately 50 $60 \mathrm{~cm}^{3}$ (cf. Birks (1991), c. $\left.160 \mathrm{~cm}^{3}\right)$. Prior to sieving each sample,

c. $10 \mathrm{~g}$ sodium pyrophosphate $\left(\mathrm{Na}_{4} \mathrm{P}_{2} \mathrm{O}_{7} \times 10 \mathrm{H}_{2} \mathrm{O}\right)$ was added, mixed and left for at least $1 \mathrm{~h}$ to disaggregate clay materials. For some samples, this step was repeated. Samples were sieved using $250 \mu \mathrm{m}$ meshes and plant macrofossils were identified using a binocular microscope and based on the reference collection at the herbarium TROM. The analyses were not intended to be exhaustive and no attempt was made to identify bryophytes.

\section{Results}

\section{Chronology and lithostratigraphy}

All 12 AMS radiocarbon dates returned plausible ages spanning $7740 \pm 40$ to $1305 \pm 30{ }^{\text {" }} \mathrm{C}$ years, corresponding to a calibrated weighted-mean range of 8477-1238 cal. BP (Table 1). The age- depth model revealed a fairly even sedimentation overall, although periods of lower sedimentation rate occurred around $530-390 \mathrm{~cm}$ depth $(8500-5500$ cal. BP) and 260-210cm depth (3800-2800 cal. BP, Figure 2). Five lithostratigraphic units (L1-L5) were identified, based on sediment structure (Supplementary Figure $\mathrm{S} 1$, available online), geochemical and lithological compositions and organic content (Figure 3). The elements $\mathrm{Si}, \mathrm{K}$ and $\mathrm{Ca}$ are assumed to characterize relative changes in input of terrigenous sediments derived from the local metamorphic bedrock. Variations in sulphur appear to track changes in organic content, and changes in Fe likely relate to redox variation. The presence of the delta close to the northern part of the basin strongly suggests that the main terrigenous sediment source has been direct input from the northern slopes rather than the drainage from Tjørnskaret pass. Aeolian input is regarded as a minor sediment source, as the catchment area wind speeds are relatively low. Consequently, the changes in minerogenic content can be regarded as a proxy for changes in slope stability and erosion from the catchment through time.

L1 (531-455cm depth, 8600-6900 cal. BP). The unit is dominated by alternating clayey laminae $(5-10 \mathrm{~mm})$ and silty beds (up to $40 \mathrm{~mm}$ thick), which are reflected in frequent (reciprocal) fluctuations in percent $\mathrm{LOI}$ and the elements $\mathrm{Si}, \mathrm{K}, \mathrm{Fe}$ and $\mathrm{S}$ (Figure 3). The thin laminae are characterized by higher LOI (up to $10 \%$ ), high $\mathrm{S}$ and lower $\mathrm{Si}$ and $\mathrm{K}$ ratios. In the thicker, silty strata, distinct peaks in $\mathrm{Si}$ and $\mathrm{K}$, together with lower $\mathrm{S}$ and percent LOI, suggest sedimentation dominated by terrigenous minerogenic input. The upper unit boundary is defined by the top

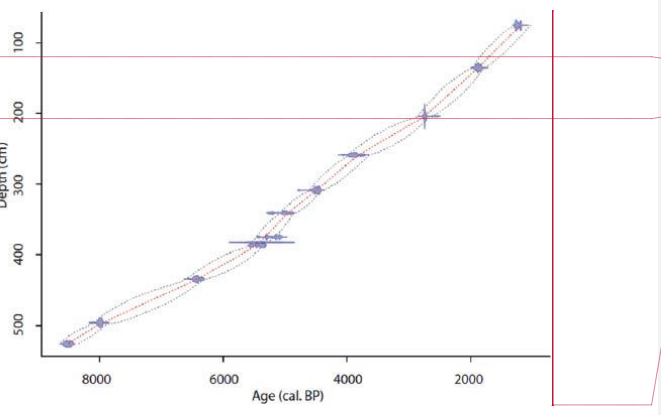

Commented [i45]: $\mathrm{s}$

Commented [i43]: (100 ml used)

Commented [i44]: $\mathrm{s}$

of the uppermost silty

Figure 2. Age-depth model for Lake Skartjørna, Svalbard.The calibrated ${ }^{14} \mathrm{C}$ dates are shown in blue, and the lines show the age-depth curve (darker grey indicate more likely calendar ages, grey stippled line show 95\% confidence interval and red line show best model based on weighted average of the mean).

bed and a marked drop in Ca. Unit L1 likely reflects alternation between low-energy hydrologic conditions with minerogenic deposition from suspension (clay), interrupted by phases of enhanced slope input from the catchment.

L2 (455-387cm depth, 6900-5500 cal. BP). A transition to more regularly alternating $2-5 \mathrm{~mm}$ thick clayey laminae occurs at $455 \mathrm{~cm}$. Si and $\mathrm{K}$ are lower and their fluctuations are smaller. This suggests more stable sedimentation, mainly from suspension, and less variable influx of minerogenic sediments, probably because of reduced runoff from the catchment. The organic contribution to the sediments as shown by the percent LOI is the highest of any unit (average LOI $8.3 \%$ as compared with average $7.3 \%$ of all samples below and average $5.6 \%$ of all samples above). Also, the $\mathrm{S}$ and $\mathrm{Fe}$ are high, likely indicating higher organic input and/or a change in redox conditions.

L3 (387-315cm depth, 5500-4600 cal. BP). A distinct drop in $\mathrm{LOI}$ to ca $5 \%$ and abrupt increases in $\mathrm{Si}, \mathrm{K}$ and sedimentation rate define the base of unit L3. The unit is dominated by 1 - to 3-mmthick laminae interrupted by successions of coarser beds up to $50-100 \mathrm{~mm}$ thick. There are large fluctuations in $\mathrm{Si}$ and $\mathrm{K}$, with peaks also associated with the reappearance of $\mathrm{Ca}$. These variations suggest a reversion to sedimentation driven by relatively high-energy terrigenous inputs.

L4 (315-165cm depth, 4600-2300 cal. BP). The unit is dominated by clayey beds. The thicker silty beds characterizing units L1 and L3 are absent. At the base of the unit is a small but distinct increase in LOI to about $6 \%$; $\mathrm{Si}$ and $\mathrm{K}$ fluctuate less than in L3 and increase gradually from $227 \mathrm{~cm}$ depth. The more fine-grained character of the sediments, the absence of the thick silty laminae and the increase in the percent LOI indicate sedimentation mainly from suspension, probably with less slope-derived influx to the basin.
Commented [i46]: BP in italics

Commented [i47]:

Commented [i49]:
Commented [i48]: BP in italics 
L5 (165-60 cm depth, 2300-1100 cal..BP). At $165 \mathrm{~cm}$, a

transition to more weakly laminated sediment occurs. The lower

boundary is also characterized by a distinct temporary drop in $\mathrm{Si}$

and $\mathrm{K}$, and the start of synchronous, larger amplitude fluctuations

of these elements. The percent LOI is generally low. Periodic

highs in Si and K may indicate episodes of higher influx of ter-

rigenous sediments to the lake from the catchment, but they are not evident as major textural changes.
Commented [i52]: BP in italics Commented [i53]: 


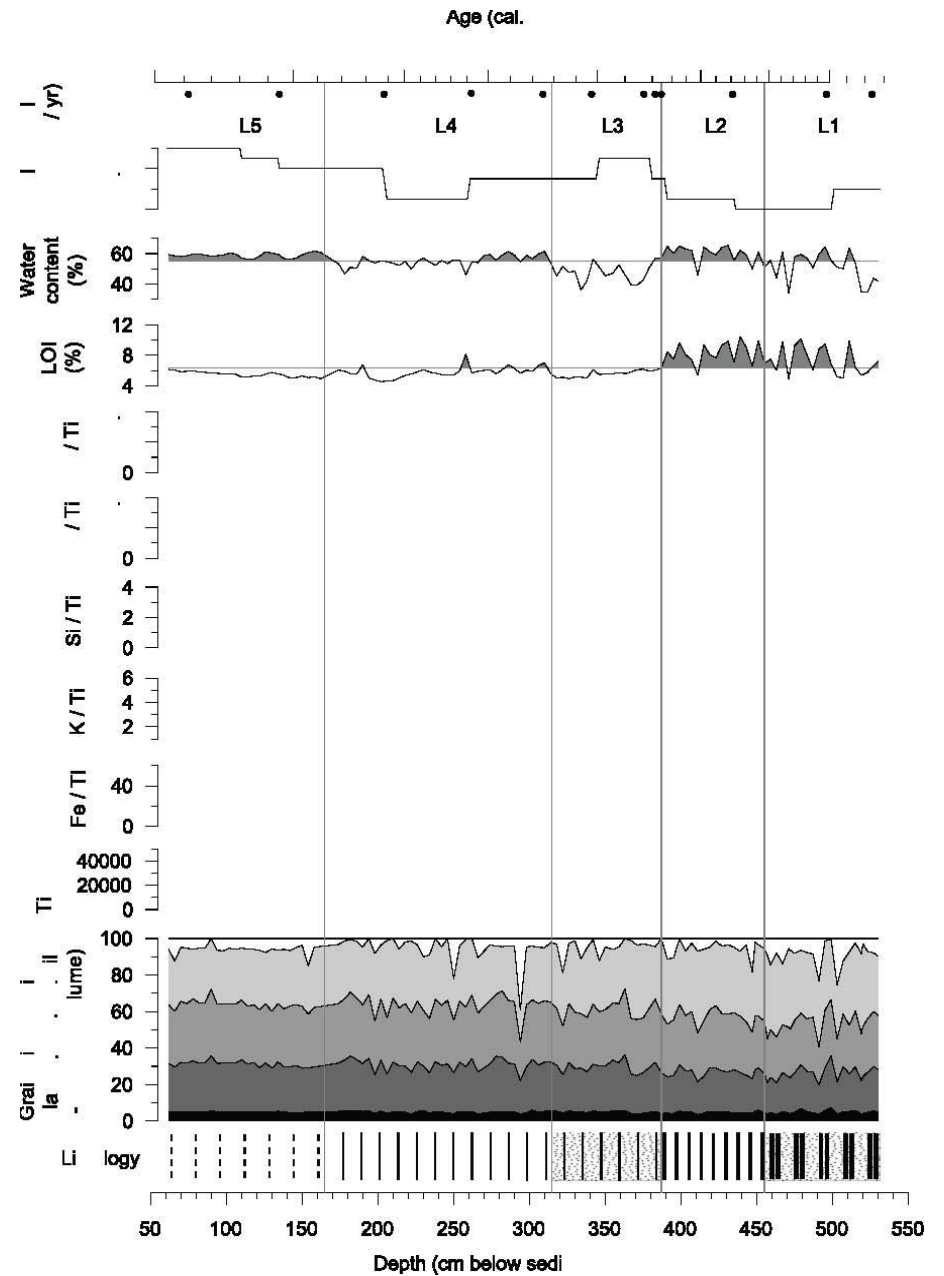

Figure 3. Sediment properties of the core from Lake Skartjørna, Svalbard. Black dots $(\cdot)$ indicate the depth of ${ }^{14} \mathrm{C}$-samples. Lithostratigraphic units (L1-L5) are

assigned to 40 samples (Supplementary Table S1, available online) After subsequent filtering, 53 taxa $(9,197,220$ reads) remained, of After subsequent filtering, 53 taxa $(9,197,220$ reads) remained, of
which 48 (9,191,407 reads) were assumed to be of local origin, marked.Water content is given as percentage wet weight. Loss-on-ignition (LOI) is given as percentage dry weight. Selected elements analysed by XRF are given as ratio to $T$, see methods). Filled areas mark values above the mean. Grain size fractions are given for clay $(<2 \mu \mathrm{m})$, fine silt $(2-8 \mu \mathrm{m})$ medium sitt $(8-16 \mu)$, coarse silt $(16-63 \mu \mathrm{m})$ and sand $(63-2000 \mu \mathrm{m})$ as percentages of total volume. The width of the ( $\times 3)$ to visibility, for high resolution photo whereas five taxa (5813 reads) were exotics (Table 2, S3).[AQ: 4] Of the 48 local taxa, 27 taxa were recorded in three or more repeats, and a further five were confirmed by macrofossils (Table 2). The identities of these 32 taxa were assumed certain. A further 16 were found in only one or two out of four PCR repeats in a sample, many likely the same as identified macrofossils, but they are interpreted with caution (Table 2, Figure 4). In total, 34 taxa of 13 families of vascular plant were identified, $32(94 \%)$ determined to genus level and $19(56 \%)$ to species level (when assuming a correct match to local taxa). In addition to the vascular plants for which the primers are designed, we also detected 12 bryophytes and two algal taxa (Table 2).

sedaDNA

Salicaceae, Oxyria digyna, Bistorta vivipara, Micranthes,

Commented [i58]:

Commented [i54]:

Commented [i55]:

Commented [i59]: in

Commented [i56]: 2

Commented [i57]: The lithology show the relative frequency and thickness of laminae (vertical bars) and the presence of coarser beds (dotted areas), 
repeats of all samples (Figure 4). Further taxa present in most samples, but with lower repeats, were the herbs Pedicularis, Silene acaulis, Cerastium, Draba and the rush Luzula. The majority of taxa identified are temperature-indifferent or weakly thermophilous in Svalbard and common in the northern arctic tundra and polar desert zones (Table 2). Three taxa that are only present in climatically more favourable sites in Svalbard today, Arabis alpina Betula and Agrostinae, have scattered occurrences in one to two repeats between 8600 and 2900,1800 and 5100 cal. BP,
Commented [i60]: Commented [i61]: 



\begin{tabular}{|c|c|c|c|c|c|c|c|c|c|}
\hline Depth $(\mathrm{cm})$ & Laboratory ID & ${ }_{14} \mathrm{C}$ age & Cal. W. mean & Cal. median & Cal. 2o range & \multicolumn{4}{|c|}{ Sample contents } \\
\hline 75.0 & Poz-58874 & $1305 \pm 30$ & 1238 & 1235.5 & $1120-1302$ & \multicolumn{4}{|c|}{$\begin{array}{l}\text { Salix polaris leaves, leaf } \\
\text { frag. }\end{array}$} \\
\hline $\begin{array}{l}135.0 \\
204.0\end{array}$ & $\begin{array}{l}\text { Poz-58875 } \\
\text { Poz-58870 }\end{array}$ & $\begin{array}{l}1930 \pm 30 \\
2600 \pm 30\end{array}$ & $\begin{array}{l}1884 \\
2746\end{array}$ & $\begin{array}{l}1874.0 \\
2746.0\end{array}$ & $\begin{array}{l}1781-1988 \\
2613-2863\end{array}$ & \multicolumn{4}{|c|}{$\begin{array}{l}\text { Salix polaris leaves } \\
\text { Salix polaris leaves, leaf } \\
\text { frag. }\end{array}$} \\
\hline 259.0 & Poz-58871 & $3580 \pm 50$ & 3810 & 3902.0 & 3629-3970 & \multicolumn{4}{|c|}{$\begin{array}{l}\text { Salix polaris leaves, leaf } \\
\text { frag. }\end{array}$} \\
\hline 309.0 & Poz-58872 & $4025 \pm 30$ & 4497 & & $4400-4624$ & \multirow{2}{*}{\multicolumn{4}{|c|}{$\begin{array}{l}\text { Salix polaris leaves } \\
\text { Salix polaris leaves, leaf } \\
\text { frag. }\end{array}$}} \\
\hline 341.0 & Poz-58873 & $4420 \pm 50$ & 4946 & 5045.0 & $4825-5080$ & & & & \\
\hline 375.5 & Poz-65652 & $4560 \pm 40$ & 5337 & 5194.5 & $5186-5472$ & \multicolumn{4}{|c|}{ Salix polaris leaves } \\
\hline 383.0 & Poz-58865 & $4700 \pm 160$ & 5424 & \multirow{2}{*}{$\begin{array}{l}5342.0 \\
5449.5\end{array}$} & $5294-5551$ & \multicolumn{4}{|c|}{ Salix polaris leaves } \\
\hline 387.0 & Poz-65653 & $4700 \pm 40$ & 5479 & & $5350-5595$ & \multicolumn{4}{|c|}{$\begin{array}{l}\text { Salix polaris leaves, leaf } \\
\text { frag. }\end{array}$} \\
\hline 434.0 & Poz-58866 & $5650 \pm 40$ & 6421 & & $6271-6594$ & \multicolumn{4}{|c|}{ Salix polaris leaves } \\
\hline 496.0 & Poz-58868 & $7170 \pm 40$ & 7945 & 7985.5 & $7736-8098$ & \multicolumn{4}{|c|}{$\begin{array}{l}\text { Moss (Drepancladus, } \\
\text { Cinclidium) }\end{array}$} \\
\hline 526.0 & Poz-58869 & $7740 \pm 40$ & $8477 \quad 8$ & 8506.5 & $8330-8604$ & \multicolumn{4}{|c|}{ Salix polaris leaves } \\
\hline Family & Taxa sedaDNA & & Taxa macrofossils & $\begin{array}{l}\text { Is } \quad \begin{array}{l}\text { Max. } \\
\text { repeats }\end{array} \\
\end{array}$ & $\begin{array}{l}\text { Sum } \\
\text { repeats }\end{array}$ & $\begin{array}{l}\text { Sum } \\
\text { reads }\end{array}$ & $\begin{array}{l}\text { Birks } \\
n\end{array}$ & $\begin{array}{l}\text { Ther } \\
\text { m. }\end{array}$ & $\begin{array}{l}\text { Zo } \\
\text { ne }\end{array}$ \\
\hline Betulaceae & \multirow{2}{*}{\multicolumn{2}{|c|}{ Betula (nana ssp. tundrarum) }} & & 2 & 5 & \multirow[t]{2}{*}{786} & & 1 & $\mathrm{C}(\mathrm{l}$ \\
\hline $\begin{array}{l}\text { Brassicacea } \\
\text { e } \\
\text { Brassicacea } \\
\text { e }\end{array}$ & & & \multicolumn{2}{|l|}{$\begin{array}{l}\text { Brassicaceae } \\
\text { undiff.2 } \\
\text { cf. Braya glabella } \\
\text { ssp. } \\
\text { purpurascens2 }\end{array}$} & & & 1 & IV & $\begin{array}{l}A( \\
r)\end{array}$ \\
\hline $\begin{array}{l}\text { Brassicacea } \\
\text { e }\end{array}$ & Arabis alpina & & Arabis alpina 1,2 & 2 & 5 & 223 & 1 & ॥ & $\begin{array}{l}B( \\
r)\end{array}$ \\
\hline $\begin{array}{l}\text { Brassicacea } \\
\text { e }\end{array}$ & Cardamine (belli & folia) & & 2 & 4 & 218 & & $\mathrm{v}$ & $\begin{array}{l}A ́( \\
f)\end{array}$ \\
\hline $\begin{array}{l}\text { Brassicacea } \\
\text { e }\end{array}$ & Cochlearia (groe & landica) & & 2 & 8 & 524 & & $\mathrm{v}$ & $\begin{array}{l}A^{\prime}( \\
f)\end{array}$ \\
\hline $\begin{array}{l}\text { Brassicacea } \\
\text { e }\end{array}$ & Draba (13 speci & & $\operatorname{Draba}_{2}$ & 3 & 47 & 5,211 & 2 & & \\
\hline $\begin{array}{l}\text { Caryophyllac } \\
\text { eae }\end{array}$ & & & Caryophyllaceae 1,2 & & & & 1 & & \\
\hline $\begin{array}{l}\text { Caryophyllac } \\
\text { eae }\end{array}$ & $\begin{array}{l}\text { Cerastium (arct } \\
\text { regelii) }\end{array}$ & um, alpinum, & $\begin{array}{l}\text { Cerastium } \\
\text { arcticum/ } \\
\text { Cerastium alpinum }\end{array}$ & Im & 44 & 2,507 & 1 & & \\
\hline $\begin{array}{l}\text { Caryophyllac } \\
\text { eae }\end{array}$ & Minuartia (rube & & Minuartia rubellaz & 1 & 3 & 86 & 1 & v & $\begin{array}{l}A( \\
f)\end{array}$ \\
\hline $\begin{array}{l}\text { Caryophyllac } \\
\text { eae }\end{array}$ & Sagina (nivalis, & espitosa) & Sagina nivalis2 & 1 & 3 & 109 & 2 & $\mathrm{v}$ & $\begin{array}{l}A( \\
r)\end{array}$ \\
\hline $\begin{array}{l}\text { Caryophyllac } \\
\text { eae }\end{array}$ & Silene (uralensis & involucrata) & & 1 & 3 & 112 & & & \\
\hline $\begin{array}{l}\text { Caryophyllac } \\
\text { eae }\end{array}$ & Silene acaulis ( & p. acaulis) & Silene acaulis 1,2 & 4 & 47 & 15,824 & 6 & IV & $\begin{array}{l}A( \\
s)\end{array}$ \\
\hline Ericaceae & & & $\begin{array}{l}\text { Harrimanella } \\
\text { hypnoides2 }\end{array}$ & & & & 1 & II & $\begin{array}{l}C( \\
\text { r) }\end{array}$ \\
\hline Juncaceae & Juncus biglumi & & Juncus2 & 1 & 3 & 50 & 5 & $\mathrm{v}$ & $\begin{array}{l}A(() \\
f)\end{array}$ \\
\hline Juncaceae & $\begin{array}{l}\text { Luzula (arcuata } \\
\text { nivalis, } \\
\text { wahlenbergii) }\end{array}$ & confusa, & Luzula2 & 4 & 77 & 10,584 & 11 & & \\
\hline $\begin{array}{l}\text { Lycopodiace } \\
\text { ae }\end{array}$ & Lycopodiaceae ( & uperzia arctica) & & 2 & 4 & 84 & & III & $\begin{array}{l}B( \\
s)\end{array}$ \\
\hline $\begin{array}{l}\text { Orobanchac } \\
\text { eae }\end{array}$ & $\begin{array}{l}\text { Pedicularis (hir } \\
\text { dasyantha) }\end{array}$ & & & 4 & 43 & 1,759 & & & \\
\hline $\begin{array}{l}\text { Papaveracea } \\
\text { e }\end{array}$ & $\begin{array}{l}\text { Papaver (dahlia } \\
\text { cornwallisense) }\end{array}$ & & Papaverz & 4 & 120 & 29,857 & 7 & & \\
\hline Poaceae & $\begin{array}{l}\text { Agrostidinae ( } \mathrm{Ca} \\
\text { neglecta) }\end{array}$ & magrostis & & 2 & 4 & 164 & & II & $\begin{array}{l}C( \\
\text { s) }\end{array}$ \\
\hline Poaceae & $\begin{array}{l}\text { Festuca (rubra, } \\
\text { hyperborea, ed } \\
\text { brachyphylla) }\end{array}$ & $\begin{array}{l}\text { affinensis, } \\
\text { ndiae, }\end{array}$ & & 4 & 23 & 2,148 & & & \\
\hline Poaceae & $\begin{array}{l}\text { (Phippsia algida, } \\
\text { concinna, } \\
\text { Hierochloë alpin }\end{array}$ & Phippsia & & 2 & 5 & 460 & & & \\
\hline Poaceae & $\begin{array}{l}\text { Deschampsia (a } \\
\text { sukatschewii) }\end{array}$ & bina, & & 3 & 9 & 298 & & & \\
\hline Poaceae & $\begin{array}{l}\text { Poeae (Poa alpi } \\
\text { Poa } \\
\text { alpina var. vivip }\end{array}$ & $\begin{array}{l}\text { a var. alpina, } \\
\text { ra) }\end{array}$ & & 4 & 38 & 2107 & & & \\
\hline Poaceae & Puccinellia (7 s & cies) & & 3 & 12 & 612 & & & \\
\hline $\begin{array}{l}\text { Polygonacea } \\
\mathrm{e}\end{array}$ & Bistorta vivipar & & Bistorta vivipara 1,2 & 4 & 156 & 406,904 & 25 & v & $\begin{array}{l}A( \\
f)\end{array}$ \\
\hline $\begin{array}{l}\text { Polygonacea } \\
\mathrm{e}\end{array}$ & Koenigia island & & & 3 & 6 & 154 & & III & $\begin{array}{l}B( \\
r)\end{array}$ \\
\hline
\end{tabular}


(Coninueos)

commented ligat 
Table 2. (Continued)

Family Taxa sedaDNA Taxa macrofossils Max. repeats Sum repeats Sum reads Birks $n$ Therm. Zone

Bryaceae Bryum 313430 N/A Bryaceae Bryaceae 26146 N/A Dicranaceae Dicranaceae 29283 N/A Ditrichaceae Distichium (capillaceum, hagenii, $1490 \mathrm{~N} / \mathrm{A}$

inclinatum) Encalyptaceae Encalypta alpina 333934 N/A Grimmiaceae Grimmiaceae 313416 N/A Arctoa (fulvella, cf. anderssonii) 29 339N/A

Rhabdowei-

siaceae Seligeriaceae Blindia acuta 14132 N/A Sphagnaceae Sphagnum 29337 N/A Timmiaceae Timmia 29322 N/A

Taxa only identified by one of the proxies are shown in blue (sedaDNA) and purple (macrofossils). Green indicates that the same taxa might have been detected with both methods; darker green indicates that the taxa were identified with a higher taxonomic resolution. Taxa identified by sedaDNA in minimum three of the four PCR repeats and/or tonfirmation by macrofossils kecord are regarded certain identifications and by maximum num 'Birks n' is num 'Birks ' is num $=$ Strongly thermophilous, $\mathrm{II}=$ Distinctly thermophilous, $\mathrm{III}=$ Moderately thermophilous, IV $=$ Weakly thermophilous, and $\mathrm{V}=$ Temperature
indifferent) follows Elvebakk (1989). Nomenclature and northernmost bioclimatic zone (A = Polar desert zone, $\mathrm{B}=$ Northern arctic tundra zone indifferent) follows Elvebakk (1989). Nomenclature and northernmost bioclimatic zone ( $\mathrm{A}=$ Polar desert zone, $\mathrm{B}=$ Northern arctic tundra $\mathrm{C}=$ Middle arctic tundra zone) where the species occurs as rare $(r)$, scattered

(s) or frequent (f) follows the PanArctic Flora checklist (Elven et al., 2011). Thermal groups and bioclimatic zones are given for the tax identified to the lowest taxonomic level; bold indicates thermal conditions warmer than present. Figure 4. Results of sedaDNA analyses from Lake Skartjørna, Svalbard. The $x$-axis refers to number of PCR repeats with 10 or
more reads. Only taxa with $100 \%$ match to reference database are included. Taxa with either $>50 \%$ successful PCR repeats in minimum one sample and/or confirmation by macrofossil are regarded as certain taxa (black), whereas taxa found in lower numbers minimum one sample and/or confirmation by macrofossil are regarded as certain taxa (black), whereas taxa found in lower numbers (D1-D3). Saxifraga taxa abbreviated as cern. (cernua), riv. (rivularis) and hyp. (hyperborea).

respectively. Three zones were identified visually based on the flora. Twenty-six of the 34 vascular plant taxa (85\%) and six of DNA data (D1-D3), the two lowermost roughly corresponding to the 12 bryophyte taxa (50\%) appear in this lowermost zone. the lithostratigraphic units L1 and L2 (Figure 4).

D2 (441-387 cm depth, 6600-5500 cal. BP). In this zone, KoeD1 (525-441 cm depth, 8500-6600 cal. BP). The zone is char-nigia islandica disappears, whereas Dryas and Saxifraga cespiacterized by relatively high values of Festuca and Poa alpina, tosa become more frequent. Ranunculaceae and Festuca are still along with Ranunculaceae. Koenigia islandica and Lycopodia-present. Also, there is a turnover of bryophytes, with four taxa ceae are limited to this zone, which also features the richest grass disappearing and three new ones appearing; Encalypta alpina appears regularly from this zone

\section{Commented [i66]:}

Commented [i67]:

Commented [i68]: 


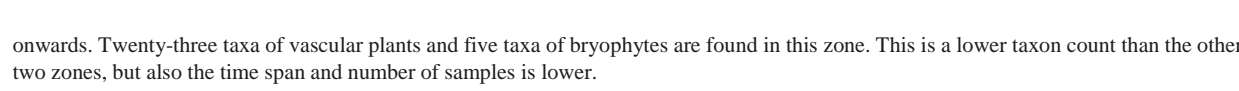


D3 (387-74cm depth, 5500-1200 cal. BP). At the transition to this zone, Festuca and Ranunculaceae disappear (but the latte reappears at $340 \mathrm{~cm}$ ), whereas nearly all species of bryophytes begin to appear regularly, including Blindia acuta and Arctoa, which are rare in Svalbard today. Overall, this zone has the highest diversity of vascular plants (32 of 34 taxa) and includes all 12 bryophyte taxa. Excep for Ranunculaceae, which is restricted to the first part of this zone, there is no clear biostratigraphic pattern.

\section{Plant macrofossils}

Three zones (M1-M3) are apparent, but the zone boundaries are not that well demarcated and do not coincide with the lithologic or sedaDNA zones (Figure 4). M1 corresponds to L1 and D1, whereas the M2/M3 boundary falls within D3 and L4 (Figure 6).

M1 (529-434cm depth, 8500-6400 cal. BP). The zone has the highest abundance and diversity of plant macrofossils. There is high but variable abundance of Salix polaris leaves. Other frequent macrofossils in this zone include Salix reticulata, Saxifraga oppositifolic Saxifraga undiff. and Silene acaulis seeds, as well as Nostoc pruniforme gelatinous spheres. Single seeds of Arabis alpina and Brassicaceae undiff. were identified from the lowermost two samples $(529-521 \mathrm{~cm}$ depth, 8500-8400 cal. BP). Samples with fewer macrofossils appear to correlate with the coarser sedimentary beds of L1

M2 (434-291 cm depth, 6400-4200 cal. BP). There is a strong drop in the overall concentration of macrofossils, and whereas the diversity is variable. This zone is characterized by a relatively high abundance of Dryas octopetala leaves. The abundance of Salix polaris leaves decreases; Salix reticulata leaves are present in the lowermost part but disappear above $397 \mathrm{~cm}$ (5700 cal. BP). No Saxifraga undiff. seeds occur above this zone. The zone displays a gradual decline in species richness from 12 taxa to four.

M3 (291-63cm depth, 4200-1100 cal. BP). This zone is defined by low abundance and diversity of macrofossils. Only Salix polaris leaves and Saxifraga oppositifolia seeds occur frequently.

\section{Correlation with other records from Skartjørna}

The core lengths and time intervals covered in this study $(530 \mathrm{~cm} ; 8600$ years) and those of Holmgren et al. (2010; $550 \mathrm{~cm} ; 8200$ years) are similar. The most significant sedimentological shift reported by Holmgren et al. (2010), a major decline in organic carbon at $415 \mathrm{~cm}$ depth ( $5400 \mathrm{cal}$. BP), can be correlated with the decline in percent LOI at the L2/L3 boundary at $387 \mathrm{~cm}(5500 \mathrm{cal}$. BP) in the present core (Figure 3).

The chronology of the $335 \mathrm{~cm}$ core analysed by Birks (1991) rests on a single basal radiocarbon date $(330-335 \mathrm{~cm}): 8110 \pm 115$ " $\mathrm{C}$ BP $(9000 \pm 400 \mathrm{cal}$. BP $2 \sigma$ error interval), plus palaeomagnetic correlation. However, an additional unpublished date at $155-160 \mathrm{~cm}$ of $2470 \pm 80{ }^{14} \mathrm{C}$ BP $(2550 \pm 130 \mathrm{cal}$. BP) was done by G. Miller 2005 (H. H. Birks and J.

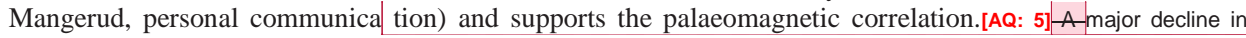
organic carbon occurs, but earlier than in the core of Holmgren et al. (2010). Birks' (1991) macrofossil record is also divided into three zones. The lowermost and uppermost zones have a similar composition to our M1 and M3. However, in Birks' record, the high concentration of Salix polaris leaves is maintained throughout the middle zone, and the boundary between the middle and upper zones is based on a subsequent decline at $c .150 \mathrm{~cm}(2600 \mathrm{cal}$. BP). The $S$. polaris leaves aside, it is possible that our M2/M3 boundary at $291 \mathrm{~cm}$ correlates with the change in Birks' (1991) record at 190cm depth, as Dryas octopetala leaves occur more frequently below both these boundaries, which date to approximately 4000 cal. BP. Thus, we conclude that the zones of Birks (1991) can be roughly correlated with our zones M1-M3.

\section{Comparison between sedaDNA and macrofossils}

All families recorded as macrofossils in either this study or the more extensive study by Birks (1991) were also found in the sedaDNA (Table 2). In addition, sedaDNA identified Betulaceae (the only local species is Betula nana ssp. tundrarum), Lycopodiaceae (only local species Huperzia arctica), Orobanchaceae (identified to Pedicularis), Poaceae (Poa alpina identified to species, Deschampsia, Festuca and Puccinellia identified to genera, one sequence identified to Phippsia or Hierochlö̈, and Agrostidinae, assigned to its only local representative, Calamagrostis neglecta).

At lower taxonomic levels, direct comparison is not always possible. For example, Brassicaceae identified in macrofossils could correspon to any or none of the four Brassicaceae taxa identified with sedaDNA (Table 2). However, all taxa found in more than one sample of macrofossils were identified with high certainty in the sedaDNA analyses (except Juncus). All but two genera identified as macrofossils (cf. Braya glabella ssp. purpurascens and Harrimanella hypnoides) were identified with sedaDNA, although some occurred in rather few PCR repeats (Table 2). Other taxa are only detected by sedaDNA, for example, Koenigia islandica, Pedicularis and different species of Poaceae (Figure 4-6, Table 2). Overall, 34 and 28 taxa of vascular plants were identified with sedaDNA and macrofossils, respectively. In many cases, the taxa were identified to species level with both methods. Macrofossils were superior in distinguishing species of Salicaceae. The numbers of taxa detected per sample were much higher for $\operatorname{sed} \mathrm{aDNA}($ mean $\pm \mathrm{SE}=15.9 \pm 0.42)$ than for macrofossils $(2.37 \pm 0.19$ and $5.83 \pm 0.57$ for this study and that of Birks (1991), respectively; Figure 6 and Supplementary Figure S2, available online).

In our record, the pattern of declining macrofossil taxon richness with time follows that of the sedaDNA, but with a much lower number of taxa overall (Figure 6). A similar decline is also observed in study of Birks (1991, Supplementary Figure S2, available online). Dominant taxa such as Salicaceae, Bistorta vivipara and Saxifraga oppositifolia are represented in all samples of both proxies. For most taxa identified with both proxies (Oxyria digyna, Saxifraga aizoides, Papaver, Arabis alpina, Minuartia, Sagina, Ranunculus pygmaeus, Dryas

Commented [i72]:
Commented [i73]:
Commented [i74]: in this zone
Commented [i75]: T
Commented [i76]:
Commented [i77]:

\section{Commented [i78]:}

Commented [i79]:

Commented [i80]: (Figures 5 and 6 )

Commented [i81]:

Commented [i82]: in

Commented [i83]:

Commented [i84]: Assuming LOI is proportional to $\mathrm{C}$, a

Commented [i85]:

Commented [i86]: Birks et al. 2004 
octopetala, Cerastium and Draba), sedaDNA detects them in more samples than do the macrofossils (compare Figure 4 with Figure 5 and Birks, 1991). For example, while macrofossils of $D$. octopetala only were found in nine samples, it was detected in 34 samples of sedaDNA (Figure 6).

\section{Discussion}

This new, well-dated record and the previous detailed plant macrofossil study of Birks (1991) together provide an excellent opportunity to assess how sedaDNA augments and/or modifies interpretations of past flora and climate in high-arctic settings. The plant materia contributing to the sedaDNA is likely derived from overland flow from melting snow beds or from rain events, erosion of material by small streams or at the lake shore and via wind deposition (possibly from more distant sources; Birks, 1991, 2004; Glaser, 1981).[AQ: 6] These are essentially the same sources as macrofossils, but sedaDNA is possibly not represented in the same proportions. In addition, DNA 


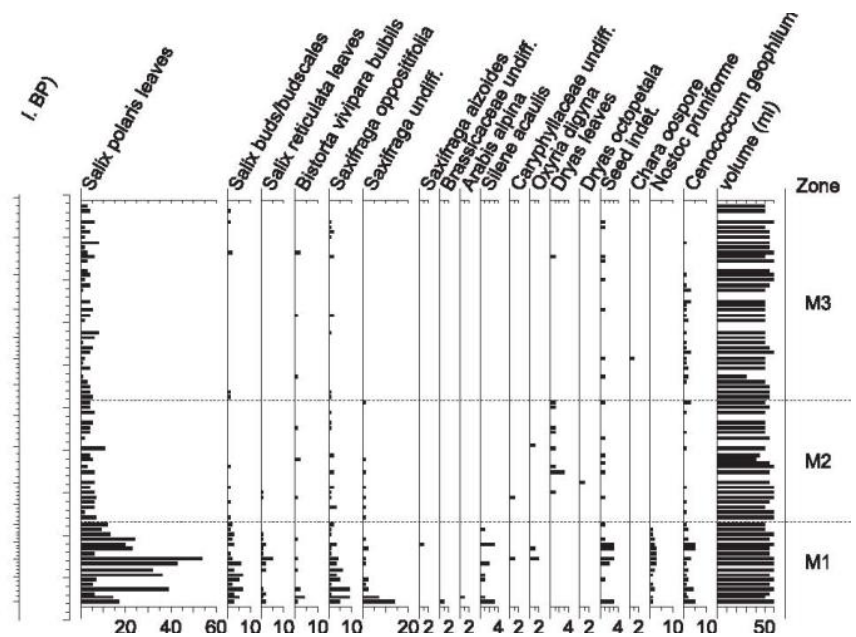

Figure 5. Macrofossils found in Lake Skartjørna, Svalbard.The x-axis refers to number of occurrences in a total volume of 50-60mL except for Nostoc pruniforme gelatinous spheres which are presented on a relative scale: (1) few (1-5), (2) moderate (6-20) and (3) abundant (>20). All plant macrofossil are seeds unless otherwise stated.Analysed by P. Sjögren, 2015. Tentative zonation based on the macrofossil results are indicated (M1-M3).

transported as complexes with other particles (England et al., 2004; Taberlet et al., 2012). |

\section{The capacity of sedaDNA to provide a record of past flora}

The sedaDNA provides a coherent record that is, in some instances, complementary to that of the plant macrofossils. For example, while sedaDNA has lower taxonomic resolution than macrofossils for the important family Salicaceae, it reveals taxa that were not present as macrofossils, such as Huperzia and several species within the Poaceae, taxa less commonly recorded in macrofossil studies. Previous sedaDNA studies from the Arctic are characterized by less overlap between sedaDNA and macro-fossils (10-35\%: Jørgensen et al., 2012 Parducci et al., 2012a, 2012b, 2013, 2015; Pedersen et al., 2013; 56\%: Porter et al., 2013). Our higher taxonomic recovery from sedaDNA likely reflects the almost complete reference library available, and possibly also the quantity of sediment used for extraction and the PCR and sequencing conditions. Only 27 of 48 taxa occurred in all four PCR repeats, suggesting that some taxa would be missed in studies that used fewer repeats. This argues for using multiple repeats to detect species with low concentrations of DNA, even though it may increas the occurrence of false positives (Ficetola et al., 2015). However, in our case, single repeats seemed to be reliable as using this threshold increased the number of local taxa by 16 (Table 2) but added only one new exotic taxon (Convallaria majalis, Supplementary Table S2, available online). Overall, the large degree of overlap in species composition between sedaDNA and macrofossils (Table 2) confirms that sedaDNA may be a reliable approach to reconstructing past vegetation.

All but one of the taxa found as macrofossils in more than one sample were identified with a conservative evaluation of the sedaDNA results (i.e. three or more PCR repeats). These taxa are widespread in Svalbard today (Alsos et al., 2015), most are typically vegetation dominants and they produce a relatively high biomass (e.g. Silene acaulis, Luzula spp., Dryas, Salix polaris, Saxifraga oppositifolia Elvebakk, 1985, 2005), and they are currently common in the catchment vegetation. The high abundance of macrofossils of Salix polaris and Saxifraga oppositifolia, for example, indicate relative high abundance in the catchment vegetation. DNA of several taxa with a generally more scattered occurrence today (e.g. Minuartia, Juncus biglumis) or at their thermal limit (Betula, Arabis alpina) was also identified, although in less than three of four PCR repeats (Table 2). This suggests that the positive correlation between biomass in vegetation and recovery in DNA found in modern soil samples (Yoccoz et al., 2012) may also apply to fossil samples from lake sediments. While Yoccoz et al. (2012) used number of reads as quantification of plant abundance in their modern soil samples, we used number of PCR repeats $(0-4)$, which is a more conservative interpretation more appropriate for aDNA.

Variation in macrofossil abundance can often be interpreted as changes in past plant abundances (Birks, 2003, 2014), but infrequent occurrences of macrofossil taxa likely reflect changes in source area (e g. fluvial input vs slope input) and a degree of serendipity in detection, with absence particularly hard to interpret. For example, macrofossils of Dryas octopetala are rarely recorded in the top zone of both macrofossil records, whereas it is present in most sedaDNA samples (Figure 6). Here, the molecular approach may be superior, as it exhibits more consistent detection of taxa.

Holocene environmental change at Skartjørna

The set of proxies retrieved from Lake Skjartørna gives insight into past environmental conditions, but many of the signals are subtle,
Commented [i88]: is

Commented [i89]:

Commented [i90]:

Commented [i91]: $\mathrm{s}$

Commented [i92]: Skartjørna

Commented [i93]: greater core deepth retrieved in

Commented [i94]: DryasShould be in italic

Commented [i95]:

Commented [i96]: reflect

Commented [i97]: 
indicating moderate environmental changes. The observed changes are discussed here primarily in conjunction with two other records from Lake Skjart@rna (Birks, 1991; Holmgren et al. 2010). Sediment properties can be heterogeneous across lake basins for a variety of reasons, and not all the proxy records agree. We assume that the longer cores of the current study as well as the one-collected by Holmgren et al. (2010) have higher influx from the erosion of the northern slope, whereas the shorter one collected by Birks (1991) might be closer to the axial inflow (Figure 1)
Commented [i98]:

Commented [i99]:

Commented [i100]:

Commented [i101]:

Commented [i102]:

Commented [i103]:

Commented [i104]: 


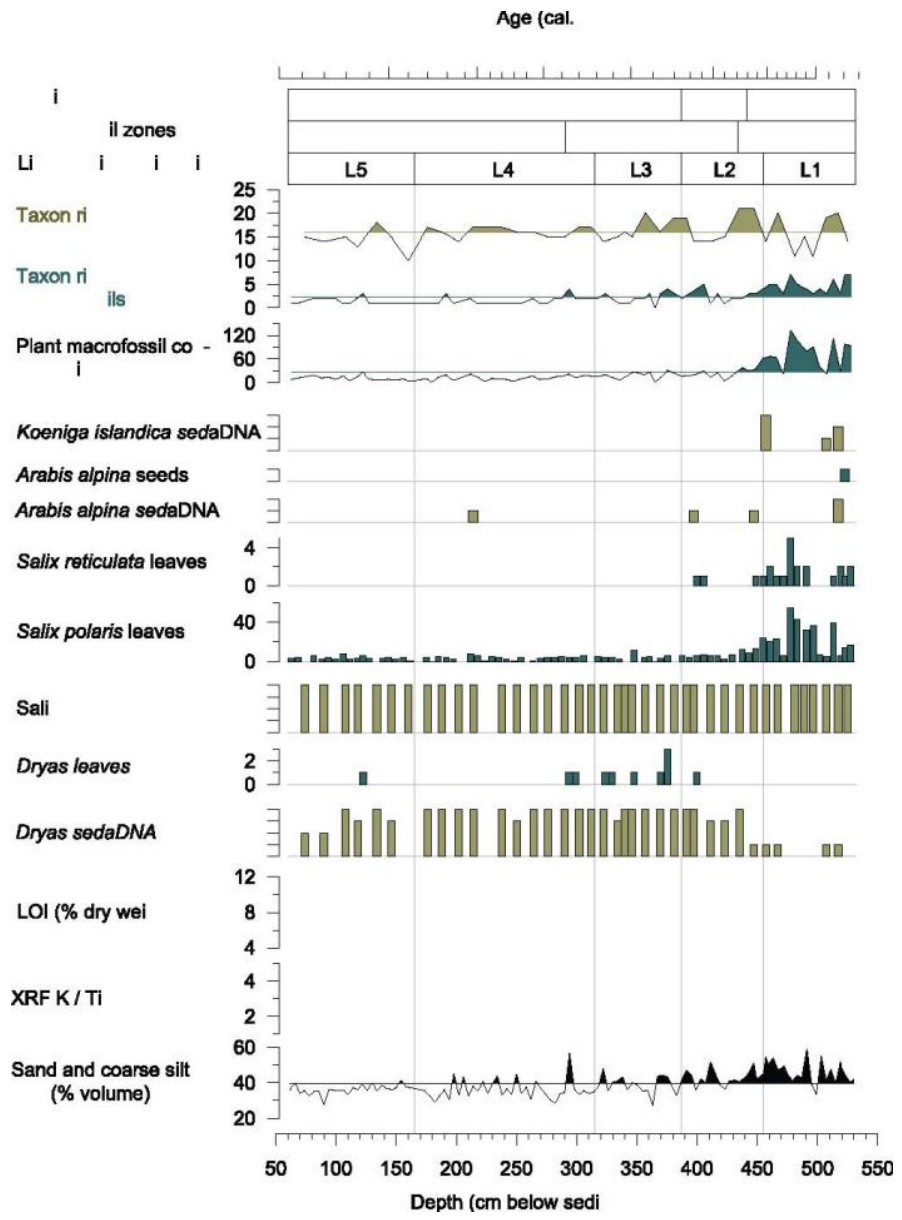

Figure 6. Comparison of zones and selected proxies. Taxon richness sedaDNA - number of vascular plant taxa per samples with one or more PCR repeats with 10 or more reads. Taxon richness macrofossils - number of identified taxa per sample as given in Figure 5. Scales of sedaDNA results are in number of PCR repeats with 10 or more reads. XRF K/sum is given as the ratio of the 11 most abundant elements. Sand and coarse silt $(16-2000 \mu \mathrm{m})$ is given as percentage volume of all fine fraction. Filled areas mark values above the mean.

Commented [i105]:

Commented [i106]

However, the main patterns in the datasets suggest a warm early Holocene and a subsequent cooling trend until the present.

Early and mid-Holocene (c. 8600-5400 cal. BP; $560-375 \mathrm{~cm}$ )

In the early part of our record ( $8600-7000 \mathrm{cal}$. BP), the high-frequency variation in \%LOI reflects the alternation of bands of silty $\lfloor$ material and more organic, fine-grained sediment, suggesting an episodic and dynamic runoff regime to the lake, possibly accentuated in the sediment record by the relative proximity of the coring site to the northern slope. The maximum organic content, as expressed by percen LOI, is relatively high for a high-arctic lake $(\sim 10 \%)$. Values decline $\sim 5500 \mathrm{cal}$. BP to $4-5 \%$. A similar overall trend in carbon content is recorded by Holmgren et al. (2010): $\sim 3 \%$ in the early record dropping to $\sim 1.5 \%$ after $\sim 5200$ cal. BP. In bur record, Nostoc, which fixes atmospheric nitrogen, is continually present from 8600-6500 cal. BP. Holmgren et al. (2010) report high diatom concentrations between 8100 and 6600 cal. BP, interpreted as relatively high overall algal productivity. Furthermore, they record low $(<10) \mathrm{C}: \mathrm{N}$ ratios for this period, which indicate dominance of autochthonous over allochthonous sources. Thus, the most likely explanation for the relatively high levels of organic karbon observed in the early part of the two records is higher biologic productivity driven by warmer growing-season
Commented [i107]: all

Commented [i108]: content

Commented [i109]: 5400

Commented [i110]:

Commented [i111]: may have

Commented [i112]: 
temperatures and/or a longer ice-free period. The distinct drop in percentage LOI around $5500 \mathrm{cal}$. BP co-occur with the emergence $\lfloor$ o silty beds in the sediment and an increased sedimentation rate, and the \%LOI values could have been suppressed by increased minerogenic inflow. High biological productivity as perceived by the \%LOI record could thus have continued for some time, and/or the decline been more subtle. The overall higher concentration and diversity of macrofossils found in our and Birks (1991) records, the higher diversity of plants found in the sedaDNA, we well as the occurrence of relatively thermophilous species in all three records also indicate that a more lush terrestrial flora was present.
Commented [i113]: $\mathrm{s}$

Commented [i114]: that

Commented [i115]: 
High levels of plant macrofossil delivery to the lake occurred between 8500 and $\sim 7000 \mathrm{cal}$. BP, declining by $6500 \mathrm{cal}$. BP to lower values, which persist through the remaining record. For much of this time (until $\sim 7000$ cal. BP), strong banding of the sediments suggest multiple high runoff events, which could have entrained plant material. The runoff events may have been intense but short-lived with much of the influx of plant material occurring gradually between events, suggesting relatively high Salix cover. Birks (1991) also report relatively high concentrations early in the record, but they persist to $\sim 2500$ cal. BP. The difference in the records may be largely because of proximity to the axial influx versus erosion of the northern slope. Given the difference between the records and the possibility of loca sedimentary variations, we recommend caution in interpreting environmental change based on this change (or lack of change) in macrofossil concentrations.

The DNA record includes taxa indicative of relative warmth (Arabis alpina and Betula nana), which first occur early (8500-6500 cal. BP) and reappear sporadically through the record until $~ 1500$ cal. BP. Arabis alpina was also found as macrofossil both in our and Birks record. In addition, Birks (1991) recorded several other thermophilous species: Harrimanella hypnoides (synonym Cassiope hypnoides, early Holocene only, $\sim 9000-8000$ cal. BP), Salix herbacea and Salix glauca (sporadic to $\sim 4000$ and $\sim 2500$ cal. BP, respectively). All the above-mentioned taxa (except Salix cf. glaucal which is extinct) are all classified as strongly or distinctly thermophilous in Svalbard today and have a northern limit in the Middle arctic tundra zone (Table 2); the records at Skjartørna lie outside their modern range limits (as much as 30km outside for Arabis alpina (nearest site Diabasbukta) and Betula (presumably Betula nana, nearest site Colesdalen; Alsos et al., 2015). All the above species also require consistent winter snow cover. Thus, the combined vegetation records, and our lithologic record, are consistent with enhanced summer warmth and relatively high levels of precipitation. Mean July temperatures may have corresponded to Middle arctic tundra zone values (minimum $6^{\circ} \mathrm{C}$, Elvebakk, 2005; Walker et al., 2005), that is, $1-2^{\circ} \mathrm{C}$ warmer than today. Other records show increased local pollen production approximately 8000-5200 cal. BP (Hyvärinen, 1968, 1969, 1970), and peat formation in western Spitsbergen island during the period 8800-4200 cal. BP also suggests a warmer climate (Göttlich and Hornburg, 1982).

The sedaDNA record after $\sim 6400 \mathrm{cal}$. BP contains taxa tolerant of dry conditions (e.g. Dryas, Andreaea, Encalypta alpina). The increase in Dryas is also clearly seen in the macrofossil record. At about the same time, the lithostratigraphic record suggests reduce and/or less variable runoff. Overall macrofossil input to the lake dropped dramatically, also $\sim 6400 \mathrm{cal}$. BP (Figure 6 ). The changes in terrestrial vegetation composition, macrofossil abundance and lithology likely reflect a change in precipitation, such as an overall reduction in winter snow cover that favoured the development of Dryas heaths on open slope and tops.

Mid- and late Holocene (5400-c. $1000 \mathrm{cal} . \mathrm{BP} ; \mathrm{G} .375-60 \mathrm{~cm})$

The sediment record (particularly lithology, K, Si and $\mathrm{Ca}$ ) suggest that the magnitude and variability of runoff increased between 5600 an $4600 \mathrm{cal}$. BP. More stable sedimentation characterized the period 4600-2300 cal. BP and then was followed by stronger pulses of minerogenic input between 2300 and 1100 cal. BP. After 5400 cal. BP, macrofossil plant species richness per sample is generally low (Figure 6, Supplementary Figure S2, available online). However, the sedaDNA data show that all taxa except three vascular plants and one bryophyte persisted after $4200 \mathrm{cal}$.

BP. Thus, most taxa recorded from the early Holocene survived locally. Drier and more open conditions are suggested by consisten presence of Dryas and Draba and the bryophytes Timmia. The catchment probably supported a geomorphologically an aspect-controlled mosaic of communities, including Dryas octopetala heath, open herb communities and moist snow-bed and drainage communities, as it does today.

The find of a Chara oospore at about $3500 \mathrm{cal}$. BP is remarklable. Today, Chara canescens is found only in warm springs on Spitsbergen The single find (not identified to species) in Skartiorna might originate from long-distance transport by birds, particularly geese (see Langangen, 2000).

The changes at Skartjørna that may signal sparser vegetation and lower biomass 5500-4000 cal. BP reflect other inferred changes in the marine and terrestrial environments. Sea-surface temperatures started to decline $c$. 7000-5000 cal. BP, and further cooling began aroun 4000 cal. BP (Rasmussen et al., 2012). On land, the nearby glacier Linnébreen re-formed around 4600 cal. BP and advanced $c .2800$ and 2400 cal. BP (Reusche et al., 2014; Svendsen and Mangerud, 1997). Overall, these observations are consistent with the onset of the Neoglaciation c. 5000-4000 cal. BP in the North Atlantic region (Miller et al., 2010).

\section{Resilience of tundra communities in the face of climate change}

A striking feature of the molecular record is that there has been little floristic turnover in the local vegetation through the Holocene, despite a decrease in vegetation productivity inferred from the macrofossils. This provides firm evidence in support of Birks' (1991) conjecture that was based on macrofossils alone. Even some thermophiles persisted (but only a single repeat of the thermophilic species Arabis alpina is recorded after $5700 \mathrm{cal}$. BP). The scattered occurrence of Betula until $1800 \mathrm{cal}$. BP, long after cooler conditions were established, may reflect its ability to survive by clonal growth under conditions too cold for sexual recruitment (Alsos et al., 2002, 2003). The combine vegetation records suggest the gradual attrition of suitable habitats for thermophiles in response to cooling and drying of the climate, but nevertheless, survival of most taxa in situ. This may be related to fine-scale heterogeneity of the landscape that supports a range of microclimates (Armbruster et al., 2007) that buffed against the overall lowering of temperature by $1-2^{\circ} \mathrm{C}$.

The Skartjørna plant records (this study, Birks, 1991) show that thermophilic species had broader distributions on Spitsbergen in the early Holocene. This is consistent with early Holocene range extensions of thermophilic species in the southernmost island of Svalbard (Bjørnøya, Wohlfarth et al., 1995), East Greenland and northern Eurasia (Bennike et al., 1999; Binney et al., 2009), and also range expansion of Betula nana in Svalbard in the early Holocene (Andersson, 1910). Based on this history, we might expect future warming of $1-2^{\circ} \mathrm{C}$ mean July temperature to drive an increase in cover and productivity and the expansion of local thermophilic species (given sufficient precipitation and conditions conducive to establishment), but not major floristic change. However, future warming is likely to reach at least $2-4^{\circ} \mathrm{C}$ mean July temperature above present; this temperature increase is unprecedented in the Holocene and may see the
Commented [i116]:

Commented [i117]: , Agrostidinae

Commented [i118]:

Commented [i119]: three

Commented [i120]:

Commented [i121]: '

Commented [i122]: a

Commented [i123]: cf.

Commented [i124]:

Commented [i125]:

Commented [i126]: van der Knaap, 1988, 1989

Commented [i127]

Commented [i128]: 4200

Commented [i129]:

Commented [i130]:

Commented [i131]:

Commented [i132]:

Commented [i133]: proxy

Commented [i134]: buffered

Commented [i135]: 


\section{Added understanding of vegetation sedaDNA compared with only macrofossils}

Because of the large degree of concurrence of taxa detected as sedaDNA and macrofossils (Table 2), one may argue that the proxies show overlap rather than being complimentary as suggested by others (Jørgensen et al., 2012; Parducci et al., 2013, 2015; Pedersen et al., 2013). However, the timing of zonation based on sedaDNA differs from that of macrofossils (Figure 6 and Supplementary Figure S2, available online), indicating that the proxies pick up different signals of change; indeed, the majority of taxa changing around 6600 and 5500 wer only recorded in sedaDNA. A more important contribution of the sedaDNA from this site is the observation that most taxa persiste throughout the period studied even though they are only found in scattered parts of the period as macrofossils. For example, only one an two macrofossils of Cerastium and Draba were found, respectively (Birks, 1991), whereas they were recorded in most sedaDNA samples (Figure 4). While these taxa tend to be ubiquitous and are components of most vegetation association in Svalbard (Elvebakk, 1994, 200 a . in the sedaDNA increases our understanding of persistence of species over time.

\section{Commented [i136]: from}

Commented [i137]:

Commented [i138]: Alsos et al. 2007

Commented [i139]: change

Commented [i140]: 


\section{Conclusion}

Our results show sedaDNA to be an effective tool for reconstructing past vegetation change in the Arctic. The taxonomic resolution was similar to macrofossil, but the latter was superior in distinguishing, for example, Salix ssp., whereas sedaDNA was superior in detecting Poaceae. Using the number of repeats as a basic estimate of abundance, sedaDNA reflects the higher biomass of common arctic taxa, and these are identified with high certainty. As with macrofossils, the likelihood of detection is probably related to abundance in the vegetation. However, more taxa were detected with sedaDNA than with macrofossil analysis, suggesting that it is more sensitive in detecting les abundant taxa. The Skartjørna record corroborates other studies in that its record of thermophilic species indicates temperatures $1-2^{\circ} \mathrm{C}$ Spifts in temperature, precipitation regime, terrestrial ecosystems and lake sedimentation. The molecular data indicate that even species with highly intermittent occurrence as macrofossil persisted throughout most of the study period. We might expect that thermophilous species that are currently highly restricted on Spitsbergen will expand again (assuming sufficient precipitation) and that both terrestrial and lacustrine productivity will increase. However, as future warming is likely to reach $2-4^{\circ} \mathrm{C}$, we may also see responses that cannot be anticipated by reference to the available Holocene records.

\section{Acknowledgements}

We thank the University Centre in Svalbard for logistic support, Henrik Rasmussen for field assistance, Frédéric Boyer for help with DNA raw data handling, Tom Bishop and Peter Langdon for help with age model, Ingvild Hald for grain-size analyses and Antony G. Brown for assessing the geology of the catchment area during a visit the 9 of September 2015 and helping with interpretation of lithology. We also thank Hilary Birks and an anonymous reviewer for very constructive comments.

\section{Declaration of conflicting interests}

Ludovic Gielly is one of the co-inventors of patents related to $g$ - $h$ primers and the subsequent use of the P6 loop of the chloroplast $t r n \mathrm{~L}$ (UAA) intron for plant identification using degraded template DNA. These patents only restrict commercial applications and have no impact on the use of this locus by academic researchers.

\section{Funding}

The work was support by the Research Council of Norway (grant nos. 213692/F20 and 230617/E10 to Alsos).

References

Alsos IG, Arnesen G, Sandbakk BE et al. (2015) The flora of Svalbard. Available at: http://svalbardflora.net.[AQ: 7]

Alsos IG, Eidesen PB, Ehrich D et al. (2007) Frequent long-distance colonization in the changing Arctic. Science 316 1606-1609.[AQ: 8]

Alsos IG, Engelskjøn T and Brochmann C (2002) Conservation genetics and population history of Betula nana, Vaccinium uliginosum, and Campanula rotundifolia in the arctic archipelago of Svalbard. Arctic, Antarctic, and Alpine Research

34: $408-418$.

Alsos IG, Spjelkavik S and Engelskjøn T (2003) Seed bank size and composition of Betula nana, Vaccinium uliginosum, and Campanula rotundifolia habitats in Svalbard and northern Norway. Canadian Journal of Botany 81: 220-231.

Anderson-Carpenter LL, McLachlan JS, Jackson ST et al. (2011) Ancient DNA from lake sediments: Bridging the gap between

Andersson G (1910) Die jetzige und fossile Quartärflora Spitzbergens als Zeugnis von Klimaänderungen [Present and fossil Quaternary flora of Spitsbergen as witness of climate change]. In: Geologenkongresses DEdI (ed.) Die Veränderungen des Klimas seit dem Maximum der letzten Eiszeit: eine Sammlung von Berichten [Climate changes since the Last Glacial Maximum - A collection of reports] (herausgegeben von dem Exekutivkomitee des 11. Internationalen Geologenkongresses). Stockholm: Generalstabens Litografiska Anstalt, pp. 409-417.

Armbruster WS, Rae DA and Edwards ME (2007) Topographic complexity and terrestrial biotic response to high-latitude climate change: Variance is as important as the mean. In: Ørbæk JB, Kallenborn R, Tombre I et al. (eds) Arctic Alpine Ecosystems and People in a Changing Environment. Heidelberg: Springer-Verlag, pp. 105-121.

Baeten NJ, Forwick M, Vogt C et al. (2010) Late Weichselian and Holocene sedimentary environments and glacial activity in Billefjorden, Svalbard. Geological Society Special Publication 344: 207-223.

Bellemain E, Davey ML, Kauserud H et al. (2013) Fungal palaeodiversity revealed using high-throughput metabarcoding of ancient DNA from arctic permafrost. Environmental Microbiology 15: 2146-2146.

Bennike O (1999) Colonisation of Greenland by plants and animals after the last ice age: A review. Polar Record 15:323-336.[AQ: 9] Bennike O (2013) Plant macrofossil records: Greenland. In: Elias SA (ed.) Encyclopedia of Quaternary Science. 2nd Edition. Amsterdam: Elsevier, pp. 760-767.

Bennike O, Björck S, Böcher J et al. (1999) Early Holocene plant and animal remains from North-east Greenland. Journal of Biogeography 26: 667-677.

Bernardova A and Kosnar J (2012) What do Holocene sediments in Petuniabukta, Spitsbergen reveal? Polish Polar Research

33: 329-345.

Bienert F, De Danieli S, Miquel C et al. (2012) Tracking earthworm communities from soil DNA. Molecular Ecology 21: 2017-2030. Bigelow NH (2013) Plant macrofossil records: Arctic North America. In: Elias SA (ed.) Encyclopedia of Quaternary Science. 2nd Edition. Amsterdam: Elsevier, pp. 746-759.

Binladen J, Gilbert MTP, Bollback JP et al. (2007) The use of coded PCR primers enables high-throughput sequencing of multiple homolog amplification products by 454 parallel sequencing. PLoS One 2: e197.
Commented [i141]: $\mathrm{s}$

Commented [i142]:

Commented [i143]: $\mathrm{s}$

\section{Commented [i144]: and}

Commented [i145]: 


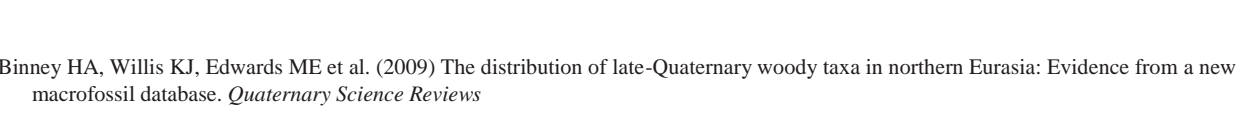


28: $2445-2464$

Birks HH (1991) Holocene vegetational history and climatic changes in west Spitsbergen - Plant macrofossils from Skardtjørna, an Arctic lake. The Holocene 1: 209-218.

Birks HH (2003) The importance of plant macrofossils in the reconstruction of Lateglacial vegetation and climate: Examples from Scotland, western Norway, and Minnesota, USA. Quaternary Science Reviews 22: 453-473.

Birks HH and Birks HJB (2000) Future uses of pollen analysis must include plant macrofossils. Journal of Biogeography 27: 31-35.

Birks HH, Paus A, Svendsen JI et al. (1994) Late Weichselian environmental change in Norway, including Svalbard. Journal of Quaternary Science 9: 133-145.

Birks HJB (2014) Challenges in the presentation and analysis of plant-macrofossil stratigraphical data. Vegetation History and Archaeobotany 23: 309-330.

Birks HJB, Jones V and Rose NL (2004) Recent environmental change and atmospheric contamination on Svalbard as recorded in lake sediments - Synthesis and general conclusions. Journal of Paleolimnology 31: 531-546.[AQ: 10]

Blaauw M and Christen JA (2011) Flexible paleoclimate age-depth models using an autoregressive gamma process. Bayesian Analysis 6: 457-474.

Blott SJ and Pye K (2001) GRADISTAT: A grain size distribution and statistics package for the analysis of unconsolidated sediments. Earth Surface Processes and Landforms 26: 1237-1248.

Collins M, Knutti R, Arblaster J et al. (2013) Long-term climate change: Projections, commitments and irreversibility. In: Stocker TF, Qin D, Plattner G-K et al. (eds) Climate Change 2013: The Physical Science Basis. Contribution of Working Group I to the Fifth Assessment Report of the Intergovernmental Panel on Climate Change. Cambridge: Cambridge University Press.[AQ: 11]

Cwynar LC (1982) A late-Quaternary history from Hanging Lake, northern Yukon. Ecological Monographs 52: 1-24.

Dallmann WK (2015) Geoscience Atlas of Svalbard. Norsk Polarinstitutt Report Series No. 148. Troms $ø$ : Norsk Polarinstitutt.

De Barba M, Miquel C, Boyer F et al. (2014) DNA metabarcoding multiplexing and validation of data accuracy for diet assessment: Application to omnivorous diet. Molecular Ecology Resources 14: 306-323.

Elvebakk A (1982) Geological preferences among Svalbard plants. Inter-Nord 16: 11-31

Elvebakk A (1985) Higher phytosociological syntaxa on Svalbard and their use in subdivisions of the Arctic. Nordic Journal of Botany 5 273-284.

Elvebakk A (1989) Biogeographical Zones of Svalbard and Adjacent Areas Based on Botanical Criteria. Tromsø: Institute of Biology and Geology, University of Troms $\varnothing, 129 \mathrm{pp}$.

Elvebakk A (1994) A survey of plant associations and alliances from Svalbard. Journal of Vegetation Science 5: 791-802.

Elvebakk A (1999) Bioclimatic delimitation and subdivision of the Arctic. In: Nordal I and Razzhivin VY (eds) The Species Concept in the High North - A panarctic flora initiative: Det Norske Vitenskaps-Akademi I. Mat.-Naturv. Klasse Skrifter, Ny serie. Oslo: Det Norske Vitenskaps-Akademi, pp. 81-112.

Elvebakk A (2005) A vegetation map of Svalbard on the scale 1:

3.5 mill. Phytocoenologia 35: 951-967.

Elven R, Murray DF, Razzhivin VY et al. (2011) Annotated checklist of the Panarctic Flora (PAF) Vascular plants. Available at: http://nhm2.uio.no/paf/

England LS, Vincent M, Trevor JT et al. (2004) Extraction, detection and persistence of extracellular DNA in forest litter microcosms. Molecular and Cellular Probes 18: 313-319.

Ficetola GF, Pansu J, Bonin A et al. (2015) Replication levels, false presences, and the estimation of presence/absence from eDNA metabarcoding data. Molecular Ecology Resources 15: 543-556.

Førland EJ, Benestad R, Hanssen-Bauer I et al. (2011) Temperature and precipitation development at Svalbard 1900-2100. Advances in Meteorology 2011: 893790

Forwick M and Vorren TO (2007) Holocene mass-transport activity and climate in outer Isfjorden, Spitsbergen: Marine and subsurface evidence. Holocene 17: 707-716.[AQ: 12]

Forwick M and Vorren TO (2009) Late Weichselian and Holocene sedimentary environments and ice rafting in Isfjorden, Spits bergen Palaeogeography, Palaeoclimatology, Palaeoecology 280: 258-274.

Fredskild J (1973) Studies in the vegetational history of Greenland. Palaeobotanical investigations of some Holocene lake and bog depostis. Meddelelser om Grønland 198: 1-245.

Giguet-Covex C, Pansu J, Arnaud F et al. (2014) Long livestock farming history and human landscape shaping revealed by lake sediment DNA. Nature Communication 5: 3211 .

Glaser PH (1981) Transport and deposition of leaves and seeds on tundra - A late-glacial analog. Arctic and Alpine Research

13: $173-182$.

Göttlich K and Hornburg P (1982) Eine Zeuge wärmezeitlicher Moore im Adventdalen auf Spitsbergen (Svalbard-Archipel) [Evidence of peatlands from the Atlantic period in Adventdalen on Spitsbergen (Svalbard Archipelago)]. Telma 12: 253-260 (in German).

Haile J, Froese DG, MacPhee RDE et al. (2009) Ancient DNA reveals late survival of mammoth and horse in interior Alaska. Proceedings of the National Academy of Sciences 106: 22352-22357.

Haile J, Holdaway R, Oliver K et al. (2007) Ancient DNA chronology within sediment deposits: Are paleobiological reconstruction possible and is DNA leaching a factor? Molecular Biology and Evolution 24: 982-989.

Hald M, Ebbesen H, Forwick M et al. (2004) Holocene pale-oceanography and glacial history of the West Spitsbergen area, Euro-Arctic margin. Quaternary Science Reviews 23: 2075-2088.

Hansen J, Hanken N-M, Nielsen JK et al. (2011) Late Pleistocene and Holocene distribution of Mytilus edulis in the Barents Sea region and its palaeoclimatic implications. Journal of Biogeography 38: 1197-1212.[AQ: 13]

and its Heiri O, Lotter AF and Lemcke G (2001) Loss ments: Reproducibility and comparability of results. Journal of Paleolimnology 25: 101-110.

Commented [i148]: 
Hjelle A, Lauritzen Ø, Salvigsen O et al. (1986) Geological map of Svalbard 1:100,000. Sheet Van Mijnfjorden. Temakart nr. 7. Tromsø: Norsk Polarinstitutt. Holmgren S, Bigler C, Ingólfsson Ó et al. (2010) The Holocene

- Anthropocene transition in lakes of western Spitsbergen, Svalbard (Norwegian High Arctic): Climate change and nitrogen deposition. Journal of Paleolimnology 43: 393-412.

Hormes A, Gjermundsen EF and Rasmussen TL (2013) From mountain top to the deep sea - Deglaciation in 4D of the northwestern Barents Sea ice sheet. Quaternary Science Reviews 75: 78-99.

Huntley B, Long AJ and Allen JRM (2013) Spatio-tempor patterns in Lateglacial and Holocene vegetation and climate of 70: $158-175$.[AQ: 14]

\section{Commented [i150]:}


Hyvärinen H (1968) Late-Quaternary sediment cores from lakes on Bjørnøya. Geografiska Annaler 50 A: 235-245.

Hyvärinen H (1969) Trullvatnet: A Flandrian stratigraphical site near Murchisonfjorden Nordaustlandet, Spitsbergen. Geografiska Annaler. Series A, Physical Geography 51: 42-45.

Hyvärinen H (1970) Flandrian pollen diagrams from Svalbard. Geografiska Annaler. Series A, Physical Geography 52: 213222.

Ingólfsson Ó and Landvik JY (2013) The Svalbard - Barents Sea ice-sheet - Historical, current and future perspectives. Quaternary Science Reviews 64: 33-60.

Jørgensen T, Haile J, Möller P et al. (2012) A comparative study of ancient sedimentary DNA, pollen and macrofossils from permafrost sediments of northern Siberia reveals long-term vegetational stability. Molecular Ecology 21: 1989-2003.

Kaufman DS, Schneider DP, McKay NP et al. (2009) Recent warming reverses long-term arctic cooling. Science 325: $1236-1239$

Kienast F (2013) Plant macrofossil records: Arctic Eurasia. In: Elias SA (ed.) Encyclopedia of Quaternary Science. 2nd Edition. Amsterdam: Elsevier, pp. 733-745.

Klimešová J, Prach K and Bernardová A (2012) Using available information to assess the potential effects of climate change on vegetation in the High Arctic: North Billefjorden, central Spitsbergen (Svalbard). Ambio 41: 435-445.

Lamb H and Edwards ME (1988) The Arctic. In: Huntley B and Webb T, III (eds) Vegetation History: Handbook of Vegetation Science 7. Dordrecht: Kluwer Academic Publishers, pp. $519-555$

Landvik JY, Bondevik S, Elverhøi A et al. (1998) The last glacial maximum of Svalbard and the Barents Sea area: Ice sheet extent and configuration. Quaternary Science Reviews 17: $43-75$.

Landvik JY, Mangerud J and Salvigsen O (1987) The Late Weichselian and Holocene shoreline displacement on the west-central coast of Svalbard. Polar Research 5: 29-44.

Langangen A (2000) Charophytes from the warm springs of Svalbard. Polar Research 19: 143-153. Mangerud J, Bolstad M, Elgersma A et al. (1992) The last glacial maximum on Spitsbergen, Svalbard Quaternary Research

38: $1-31$

Miller GH, Brigham-Grette J, Alley RB et al. (2010) Temperature and precipitation history of the Arctic. Quaternary Science Reviews 30: 2841-2843.

Nesje A (1992) A piston corer for lacustrine and marine sediments. Arctic and Alpine Research 24: 257-259. Ohta Y, Hjelle A, Dallmann WK et al. (1991) Geological map of Svalbard. Sheet B9G Isfjorden. Norsk Polarinstitutt Temakart 16: 1-52. Overpeck J, Hughen K,

Hardy D et al. (1997) Arctic

environmental change of the last fou

centuries. Science 278: 1251-1256.

Pansu J, Giguet-Covex C, Ficetola GF et al. (2015) Reconstructing long-term human impacts on plant communities: An ecological approach based on lake sediment DNA. Molecular Ecology 1485-1498.

Parducci L, Edwards ME, Bennett KD et al. (2012a) Response to comment on 'Glacial Survival of Boreal Trees in Northern Scandinavia', Science 338: 742 .

Parducci L, Jørgensen T, Tollefsrud MM et al. (2012b) Glacial survival of boreal trees in northern Scandinavia. Science 335: 1083-1086
Parducci L, Matetovici I, Fontana SL et al. (2013) Molecular- and pollen-based vegetation analysis in lake sediments from centra Scandinavia. Molecular Ecology 22: 3511-3524.

Parducci L, Väliranta M, Salonen JS et al. (2015) Proxy comparison in ancient peat sediments: Pollen, macrofossil and plant

DNA. Philosophical Transactions of the Royal Society of London Series B: Biological Sciences 370: 20130382.

Pawlowska J, Lejzerowicz F, Esling P et al. (2014) Ancien DNA sheds new light on the Svalbard foraminiferal fossil record of the last millennium. Geobiology 12: 277-288.

Pedersen MW, Ginolhac A, Orlando L et al. (2013) A comparative study of ancient environmental DNA to pollen and macrofossils from lake sediments reveals taxonomic overlap 161-168.

Pedersen MW, Overballe-Petersen S, Ermini L et al. (2015) Ancient and modern environmental DNA. Philosophical Transactions of the Royal Society of London Series B: Biological Sciences 370: 20130383.

Porter TM, Golding GB, King C et al. (2013) Amplicon pyrosequencing late Pleistocene permafrost: The removal of putative contaminant sequences and small-scale reproducibility. Molecular Ecology Resources 13: 798-810.

Rasmussen TL, Forwick M and Mackensen A (2012) Reconstruction of inflow of Atlantic Water to Isfjorden, Svalbard during the Holocene: Correlation to climate and seasonality. Marine Micropaleontology 94-95: 80-90.

Rasmussen TL, Thomsen E, Skirbekk K et al. (2014) Spatia and kemporal distribution of Holocene temperature maxima in the northern Nordic seas: Interplay of Atlantic-, Arctic- and polar water masses. Qunternary Science Reviews 92: 280 291.[AQ: 15]

Reimer PJ, Bard E, Bayliss A et al. (2013) IntCal13 and marine 13 radiocarbon age calibration curves $0-50,000$ years cal BP. Available at: https://journals.uair.arizona.edu/index.php/ radiocarbon/article/view/16947.

Reusche M, Winsor K, Carlson AE et al. (2014) "'Be surface exposure ages on the late-Pleistocene and Holocene history of Linnébreen on Svalbard. Quaternary Science Reviews 89: 5-12.

Rozema J, Boelen P, Doorenbosch M et al. (2006) A vegetation, climate and environment reconstruction based on palynological analyses of high arctic tundra peat cores (5000-6000years BP) from Svalbard. Plants and Climate Change 41: 155-174. Serebryannyy LP, Tishkov AA, Malyasova YE et al. (1985)

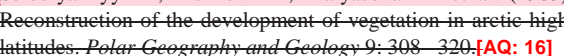
Slubowska-Woldengen M, Rasmussen TL, Koç N et al. (2007) Advo Swalf 17,500 BP. Reviews 26: 163-478. [AQ: 17]

Soininen EM, Gauthier G, Bilodeau F et al. (2015) Highly overlapping diet in two sympatric lemming species during winter revealed by DNA metabarcoding. PLoS One 10: e0115335.

Sønstebø JH, Gielly L, Brysting AK et al. (2010) Using next-generation sequencing for molecular reconstruction of past Arctic vegetation and climate. Molecular Ecology Resources 10: 1009-1018. Svendsen JI and

Mangerud J (1997) Holocene glacial and

climatic variations on Spitsbergen,

Svalbard. The Holocene 7: 45-57.

Taberlet P, Coissac E, Pompanon F et al. (2007) Power and
Commented [i151]:

Commented [i152]:

Commented [i153]: 
limitations of the chloroplast trnL (UAA) intron for plant DNA barcoding. Nucleic Acids Research 35: e14.

Taberlet P, Prud'Homme SM, Campione E et al. (2012) Soil sampling and isolation of extracellular DNA from large amount of starting material suitable for metabarcoding studies.
Molecular Ecology 21: 1816-1820.

Tjallingii R, Röhl U, Kölling M et al. (2007) Influence of the water content on X-ray fluorescence core-scanning measurements in soft marine sediments. Geochemistry, Geophysics, Geosystems 8: Q02004. 
Valentini A, Miquel C, Nawaz M et al. (2009) New perspectives in diet analysis based on DNA barcoding and parallel pyrosequencing: The trnL approach. Molecular Ecology Resources 24: 110-117.

Walker DA, Raynolds MK, Daniels FJA et al. (2005) The circumpolar arctic vegetation map. Journal of Vegetation Science 16: 267-282.

Weltje GJ and Tjallingii R (2008) Calibration of XRF core scanners for quantitative geochemical logging of sediment cores: Theory and application. Earth and Planetary Science Letters 274: 423-438.

Werner K, Spielhagen RF, Bauch D et al. (2013) Atlantic Water advection versus sea-ice advances in the eastern Fram Strait adveet verstrat during the last 9ka: Multiproxy evidence for a two phase Holocene. Pde centugraphy 28: 283-295. [AQ: 18]

Willerslev E, Cappellini E, Boomsma W et al. (2007) Ancient biomolecules from deep ice cores reveal a forested southern Greenland. Science 317: 111-114.

Willerslev E, Davison J, Moora M et al. (2014) Fifty thousand years of Arctic vegetation and megafaunal diet. Nature 506: 47-51.

Willerslev E, Hansen AJ, Binladen J et al. (2003) Diverse plant and animal genetic records from Holocene and Pleistocene sediments. Science 300: 791-795.

Wohlfarth B, Lemdahl G, Olsson S et al. (1995) Early Holocene environment on Bjørnøya (Svalbard) inferred from multidisciplinary lake sediments studies. Polar Research 14: 253-275.

Xu L, Myneni RB, Chapin III FS et al. (2013) Temperature and vegetation seasonality diminishment over northern lands. Nature Climate Change 3: 581-586.

Yoccoz NG, Bråthen KA, Gielly L et al. (2012) DNA from soil mirrors plant taxonomic and growth form diversity. Molecular Ecology 21: 3647-3655.

Commented [i154]: van der Knaap WO (1988) Deposition of long-distance transported pollen and spores since 7900 B.P. studied in peat deposits from spore Spitsbergen. Pollen et Spores XXX: 409-416.van de Knaap WO (1989) Past vegetation and reindeer on Edgeøya (Spitsbergen) between c. 7900 and 3800 BP, studied by means of peat layers and reindeer faecal pellets. Journal of Biogeography 16: 379-394.

\section{Commented [i155]:}

